\title{
Ciemne światło wojny
}

Tadeusz Sławek

TEKSTY DRUGIE 2018, NR 4, S. 170-191

DOI: $10.18318 /$ td.2018.4.10

\section{Pamięci Cezarego Wodzińskiego}

Wojna ta jest nie tylko bardziej krwawa niż wszystkie poprzednie z powodu wielkiego rozwoju środków ataku i obrony, jest przynajmniej tak samo okrutna, gorzka i bezwzględna jak poprzednie. Wykracza poza wszystkie ograniczenia ustalone dla czasu pokoju, poza tzw. prawa narodów, nie uznaje praw rannych ilekarzy, nie czyni różnicymiędzy żotnierzami i cywilami, nie szanuje własności. Rzuca się z wściekłościa na wszystko, co stanie na jej drodze, jak gdyby po tej wojnie nie miało już być ani przyszłości, ani pokoju. Rozrywa więzy wspólnotowe między walczacymi ludami i zostawia za soba gorycz, która uniemożliwi na długi czas ponowne ich nawiazanie.

Zygmunt Freud Refleksje o wojnie i śmierci.

1.

Co jest następstwem wojny w sferze ducha? Po pierwsze, pytanie o to, czy wojna jest prawidłowością historii, o historię jako dzieje wojen, historię jako rodzaj inteligencji wytwarzającej wojenną zagładę. Pytamy o to, czy historia musi być apokaliptyczna. W 1919 roku Siegfried Sassoon

\footnotetext{
Tadeusz Sławek

- prof., związany

z Uniwersytetem Ślą-

skim od 1971 r., rektor

tegoż Uniwersytetu

w latach 1996-2002.

Wraz z kontraba-

sistą Bogdanem

Mizerskim autor

i wykonawca esejów

na głos i kontrabas.

Zajmuje się historią

literatury angielskiej

i amerykańskiej, lite-

raturą porównawczą,

zagadnieniami życia

publicznego. Ostat-

nio opublikował:

NIC-owanie świata.

Zdania z Szekspira

(2012), U-chodzić

(2015). Nie bez reszty.

O potrzebie niekom-

pletności (2018).
} 
trapił tym zagadnieniem tych, którzy wyszli cało z okopów wojny: „Czy kiedyś zatrzymasz się, by spytać, «Czy to wszystko znów ma się powtórzyć?» [Doyou ever stop and ask, 'Is it all going to happen again?']"'. Amnezja jest procesem, który skutecznie otwiera możliwość powtarzania się wojny. W krótkim tekście parokrotnie ujawnia się wyraźny niepokój o to, że niepamięć wymaże wszelkie mechanizmy ostrzegawcze. „Czy pamiętasz?”, powtarza Sassoon rok po Wielkiej Wojnie, przywołując obrazy śmierci i zniszczenia. Jednak chodzi nie tyle o niepamięć wymazującą dane z przeszłości. Stawka jest wyższa i bardziej dramatyczna, bowiem nawet skromna znajomość historii pozwala zobaczyć, że przeszłość staje się polem politycznej gry dowolnie selekcjonującej i zestawiającej zdarzenia. Rzecz nie w prostym usunięciu, lecz w zniekształcającej manipulacji. Polityka historyczna jest de-formacją pamięci. Mniej interesuje ją przeszłość jako ostrzeżenie będące źródłem pożądanego namysłu; znacznie bardziej zajmuje się przygotowywaniem i narzucaniem gotowych rekonstrukcji przeszłych zdarzeń jako instrumentu politycznego kreowania teraźniejszości. Namysł ma zdolność ocalania, stwarzając przestrzeń, w której możliwe jest pojednanie; polityka historyczna nie jest zainteresowana ocalaniem niczego, prócz własnych interesów, a więc nie pojednanie a generowanie potencjalnych konfliktów/wojen będzie jej zadaniem.

\section{2.}

Po drugie, jeśli z całą powagą, a nie jedynie dla retorycznego popisu, pytamy „Czy to wszystko znów ma się powtórzyć?", musimy zatroszczyć się o to, co właściwie ma zostać zapamiętane. Nie chcąc wymazać wszystkiego i broniąc się przed nadużyciami polityki historycznej, nie wolno nam nie zbadać tego czegoś, co nie tylko mamy pamiętać, ale co kryje w sobie siłę apotropaiczną, mogącą w przyszłości odstraszyć przerażające wydarzenia. Wyraźnie słyszymy podpowiedź wojennego weterana: tylko to, co dotkliwie, fizycznie bliskie, co pozbawione ideologicznej mocy, tylko to, co dotykalne w swej materialności jednostkowego ciała i jego męki - tylko to może, jeśli będzie zapamiętane, ocalić. Sassoon przywołuje obrazy worków z piaskiem wzmacniających czoło okopu, szczury, odór rozkładających się zwłok, zmęczone twarze żołnierzy gotujących się do ataku. Nie ma ani słowa o narodzie, państwie, honorze czy fladze. Moc tych obrazów jest podwójna: budzą grozę okrucieństwem

1 S. Sassoon Aftermath, w: Poetry of the First World War, ed. by M. Hussey Longmans, London 1967, s. 158. 
wojennych zmagań dotykających jednostkę, ale ich bezwzględna surowość właśnie dlatego, że w sposób dosłowny dotyka jednostkę, ma przypomnieć o tym, co kryje się za owymi obrazami. Mają one przypomnieć o tym, czym jest (zdradzone) życie. Tragiczny paradoks wojny: walcząc o prze-życie, zapominam, czym jest $\dot{z y c i e . ~ W ~} 1922$ roku e.e. cummings w medytacji z czasów wojny musi sobie przypomnieć znaczenie i koniugację czasownika „żyć”: "czym jest Paryż? - jakieś miejsce, gdzieś tam, miasto, życie; (żyć: bezokolicznik. Pierwsza osoba liczby pojedynczej: ja żyję. Ty żyjesz)"2. Patrząc na twarze żołnierzy w okopie, Sassoon dostrzega przedstawicieli życia-po-życiu. Wojna maskuje życie. Wielka Wojna, przynosząc sztukę militarnego kamuflażu, zamaskowuje również egzystencję. Przywołajmy poetę mówiącego o „spopielałych twarzach / Co są maskami chłopaków kiedyś tak pełnych życia, życzliwych, wesołych”. Jeśli „to wszystko nie ma się znów powtórzyć”, musimy bronić się przed wizerunkami wojny dokonującymi de-formacji pamięci oraz uczyć odczytywania znaków wojny jako nieuchronnej de-formacji życia i zdrady wobec niego popełnionej. Ludzie poddani działaniu wojny, ,to ludzie, którym śmierć umysły zrabowała"3. Podobnie Józef Wittlin będzie mówił o wojnie jako o reduktywnej operacji niwelującej bogactwo doświadczania świata do kategorii swój/wróg, co poeta nazywa zatruwaniem serc: „Serce mam strute. / Oto kazali mi pogrzebać wroga, co zginął w bitwie. / Do ręki mi dali łopatę, palcem wskazali: wróg! [...] / Czy chłop, czy pan, czy robotnik, / Czy podły człek, czy szlachetny - / Wiem tylko jedno: wróg"4.

\section{3.}

Po trzecie, wojna jest dramatycznym przypadkiem szczególnego, znów de-formującego, udziału człowieka w czasie, co wymaga od nas refleksji nad relacją między życiem a czasem. Czytając wiersz Sassoona, przekonujemy się, że wojna stanowi swoistą wyrwę w chronometrii egzystencji. Jest początkiem czegoś, co może w skali ogólnoświatowej było przewidywalne i w ten sposób wpisywało się w nieprzerwaną ciąłłość historii (w 1910 roku Wincenty Lutosławski pisał w tym duchu „Choć od trzydziestu lat panuje pokój w Europie, to pokój ten pełen jest zapowiedzi wojny, i wojna jest przede wszystkim

2 e.e. cummings The Enormous Room, Dover Publications, Mineola-New York 2002, s. 188.

3 W. Owen Obłąkani, przeł. J. Wittlin, w: Czas niepokoju. Antologia współczesnej poezji brytyjskiej iamerykańskiej, ed. P. Mayewski, Criterion Books, New York 1958, s. 237.

4 J. Wittlin Grzebanie wroga, w: tegoż Poezje, PIW, Warszawa 1978, s. 31. 
oczekiwana"5), lecz dla jednostki stanowiło gwałtowny wstrząs wyrzucający ją z koleiny jej czasu w czas, który wchłaniał ją i mieszał z innymi w jednolitą masę. Pisze Barbara Skarga, że „chociażby historyk dowodził, że początek wydarzeń należy przesunąć znacznie w przeszłość, a poszczególne fakty wyjaśnić w ramach większej historycznej całości, uczestnikowi wydarzeń zmiana, w istocie przygotowana przez splot okoliczności wydaje się radykalna. Spojrzenia historyka i świadka nie są z sobą zgodne. Być może, prawdziwa jest opinia historyka, istnieje jednak także prawda egzystencjalna, prawda przeżycia lub, inaczej, prawda ludzkiego doświadczenia". Uwięziony w pułapce wojny poeta najpierw spyta "gdzie w tym wszystkim, jeśli w ogóle, jest Czas?" i odpowie, diagnozując rozpryśnięcie się sekwencyjności wydarzeń: „zdarzenia już nie następują po sobie; cokolwiek się zdarza, chociaż mogłoby się wydarzyć w powiązaniu z innymi, odległymi wydarzeniami, nie znajduje miejsca na skali chronologicznego uporządkowania - każde zdarzenie bowiem jest teraz samowystarczalne i nie zważa na minuty, miesiące i tym podobne skarby wolności"7.

\section{4.}

Z wnikliwego tekstu Barbary Skargi płyną dla nas dwa wnioski: najpierw ten, że wojna to radykalny wstrząs znaczący początek innego sposobu doświadczania świata i czasu; a następnie - że ten radykalny, tektoniczny ruch dokonujący się w naszej egzystencji uświadamia nam, że jesteśmy uczestnikami i świadkami, a nie wyłącznie tymi, którzy biernie odnajdują się w przepływie wydarzeń. Franz Pfemfert znalazł dla owego okresu zapoczątkowanego dramatycznym zachwianiem trafną formułę: „Pod władzą Marsa stanęły godziny"8. Jeśli umysł towarzyszy nieprzerwanemu trwaniu czasu, wojna wyrywa go z owego strumienia, wyciąga niejako na brzeg, zawieszając wszystkie dotychczasowe kształty zdarzeń. „Rabuje mu umysł”, napisałby Owen. To (wróćmy do wiersza Sassoona) „nawiedzona luka w umyśle, którą znów wypełnił ruch myśli płynących / Niczym chmury na jasno oświetlonym niebie

5 W. Lutosławski Ludzkość odrodzona. Wizje przyszłości, Gebethner i Wolff, Warszawa 1910, s. 27. Dalej oznaczone jako $L O$ z numerem strony.

6 B. Skarga Kwintet metafizyczny, Universitas, Kraków 2005, s. 72.

7 e.e. cummings The Enormous Room..., s. 67.

8 F. Pfemfert Pod władzą Marsa stanęły godziny, przeł. R. Turczyn, "Literatura na Świecie" 1983 nr 10, s. 186. 
życia". Jan Patočka prowadzi swą krytyczną refleksję o wieku XX jako wojnie w stronę Heraklita, który przynajmniej w dwóch miejscach związał swoje myślenie z konfliktem. Słynny fragment 53 mówi o boju (polemos) będącym „wszystkich ojcem, wszystkich królem”, a to rozpoznanie dopełnia fragment 8o., z którego dowiadujemy się, że wojna (polemos) „jest powszechna i sprawiedliwość to niezgoda"9. Zdaniem Patočki splot tych dwóch myśli rodzi paradoksalną dialektykę wojny, która bez wątpienia dzieląc (i w tym sensie zapowiadając Schmittowską dychotomię przyjaciel/wróg), jednocześnie łączy strony niezgody. Ich zmagania są wspólnymi zmaganiami ze zrutynizowaną praktyką „pokoju”. Wojna zatem to nie-zgoda lub też nie-pokój.To drugie pojęcie pojawia się u Johannesa Bechera, który zadawszy nowoczesnemu człowiekowi pytanie, czy jest „wściekłym molochem czy brzegiem Edenu” i przedłużywszy je w kolejne „Miotaczem trującego gazu czy ziarnem zbawienia”, przedstawi jego los jako efekt dramatycznego zachwiania dotychczasowego ładu dnia: „W altanę drzemki i oazę twych stóp / zanurza się nie-pokój”"10. To, co do tej pory było ostoją solidności, teraz chwieje się i rozmywa. To właśnie zaakcentuje czeski filozof: „[...] polemos nie jest czymś jednostronnym, nie dzieli, lecz łączy; nieprzyjaciele tylko pozornie są całością każdy dla siebie, w rzeczywistości zaś wzajemnie do siebie należą we wspólnym zachwianiu dnia powszedniego [... $]^{\prime 11}$.

\section{5.}

Wojna jest więc, uczy Sassoon, rozpadliną myślenia, zarwaniem się traktu myśli. Nie znaczy to, że jest bez-myślna. Nie, trzeba raczej rzec, że jest innym trybem myślenia, mimo całej oprawy militarno-biurokratycznej jest to myślenie jakby nieoficjalne, niecodzienne, nawet upiorne, skoro mowa o nawiedzaniu, może nawet wręcz o straszeniu (the haunted gap in your mind). Wojna to myślenie, które straszy w umyśle zrujnowanym przez wytwory i dyscyplinę kalkulacyjnego, stechnicyzowanego rozumu. Luka, o której mowa, to jakby odpowiednik zniszczonej wojną przestrzeni mieszkalnej. Ani spacjalizująca metafora, ani widmowy charakter myślenia nie są tu przypadkowe. Dowiadujemy się, że wojna to myślenie, które lęka się światła,

9 K. Mrówka Heraklit, Scholar, Warszawa 2004, S. 167, 225.

10 J. Becher Człowieku, powstań!, przeł. J. Buras, „Literatura na Świecie” 1983 nr 10, s. 183.

11 J. Patočka Wojny XX wieku i wiekXX jako wojna, przeł. J. Zychowicz, w: tegoż Eseje heretyckie z filozofii dziejów, Aletheia, Warszawa 1998, s. 187. 
a skoro światło jest atrybutem życia, zatem wojna jawi się jako myślenie nawiedzające życie jako siła mu wroga; jeśli dysponuje jakimś światłem, jest to blask lucyferyczny. Nie ma on nic wspólnego z „niebem”. Przeciwnie, odnajdziemy go w Miltonowskiej wizji piekła: „obszar pusty i posępny; / Loch ów straszliwy, który go otacza / Jak palenisko rozległe, płonące; / Jednak nie pada blask z owych płomieni, / Lecz raczej ciemność widoma..."12. Taki też obraz odszukamy u Ernsta Jüngera: „O północy zaczął się piekielny spektakl na łuku pozycji bojowych [...]. W poświacie rac jak walec przetaczała się oślepiająca rzeka gazu przez czarne blanki obmurowań. A jako że i w kopalni można było wyczuć ostrą won chloru, rozpaliliśmy przed wyjściem wielkie ogniska ze słomy, których żrący dym omal nie wygnał nas ze schronienia $[\ldots]^{\prime \prime 13}$.

\section{6.}

W ciemnym świetle bez blasku (jego liczne przykłady odnajdziemy w wielu opisach bitewnych pól, Sassoon mówi o "ciemnych miesiącach, kiedy broniłeś sektora pod Mametz”) myśli nie „płyną", lecz zostają zatrzymane. Wojna to myśl zatrzymana w swoim biegu, myśl okopana i ściśle pozycyjna w tym sensie, że ujawniają się tylko (niczym szpilki znaczące pozycje wojsk na sztabowej mapie) jej ideologiczne rozbłyski (np. retoryczne deklaracje patriotyzmu), natomiast jej myślowa aparatura zostaje głęboko ukryta w ciemności. Myśli należące do życia i życie tworzące „płyną” (flow); myśl wojny zagłębia się w siebie, ginie ze wzroku, kryje się, przypada do ziemi, jej życie jest życiem utajonym. To jeden z powodów, dla których wojna wydaje się przygasać, lecz nie wygasać. Widoczne są jej ofiary, lecz siła ofiary te sprawująca pozostaje bezpiecznie ukryta w podziemnym schronie. Jedna z najwybitniejszych artystek wojennych czasów Käthe Kollwitz pyta dramatycznie, czy wojna nadużywa gotowości młodych ludzi do ofiary dla swych celów, kto - jeśli w ogóle da się to ustalić - jest temu winny, czy wszyscy padli ofiarą wielkiego oszustwa, a może mamy do czynienia ze zbiorowym szaleństwem. Znamienne są te zastrzeżenia, mnożące się zdania warunkowe („jeśli da się to ustalić") - jakby Kollwitz wiedziała, że ma do czynienia z przebiegłym przeciwnikiem ukrytym w podziemnych korytarzach. Stąd i wyznanie końcowe:

\footnotetext{
12 J. Milton Raj utracony, przeł. M. Słomczyński, Wydawnictwo Literackie, Kraków 1974, s. 10.

13 E. Jünger Wstalowych burzach, przeł. W. Kunicki, Czytelnik, Warszawa 1999, s. 76.
} 
"Ciągle staram się przedstawić wojnę. Nigdy nie zdołałam jej uchwycić"14. Freud w swej analizie wojny dowiedzie, że owa niepochwytność wojny bierze się z niewyczerpanych źródeł agresji skrytej, okopanej w schronach podświadomości

\section{7.}

Tęsknota zabijania spycha ludzi w głąb ziemi. To Isaac Rosenberg. Ale żeby dojść do takiego wniosku, trzeba porzucić przymusowy szlak dobrze wytyczony przez retoryczne tropy wojennego myślenia. Trzeba zostawić za sobą metaforykę wzniosłości i wielkich haseł, powierzając się temu, co małe i znikome, lecz co niczym ostra szpilka zdolne jest do przebicia wielkiego balonu. Nie oficjalny patriotyzm, lecz „przerażone serce” (heart aghast), nie orzeł lub dostojne heraldyczne zwierzę, lecz „szczur”. Rosenberg, spoglądając na szczura przemykającego okopami i drwiąco ignorującego linie armijnych i narodowych podziałów, szczura o „kosmopolickich sympatiach” (cosmopolitan sympathies), zyskuje punkt widzenia, który można nazwać nie-ludzkim. To niezwykła lekcja wojny, którą trzeba odrobić, jeśli „to wszystko nie ma się znów powtórzyć": nieludzkość dziejów da się, być może, skorygować poprzez to, co nie-ludzkie, a co obejmie zarówno zwierzę jak i Boga. Dzisiejsze animal studies i teologia śmierci Boga są źródłem ostrożnej nadziei. Nie-ludzkie pozwala bowiem na spojrzenie z dystansu, odwrócenie Swiftowskiej lunety, gest brutalnie odsłaniający próżność ludzkich ambicji do racjonalności i pretensji do chwały. „Śmiać się będziesz”, mówi Rosenberg do szczura, „że wzniośli atleci, ich znakomite mięśnie i wspaniałe oczy / mniej znaczą, niźli twoje życie, / gdy oni związani tęsknotą zabijania / tarzają się w trzewiach ziemi, / w rozdartych polach Francji”'15. Oryginał jest surowszy niż przekład: „tęsknota” to w istocie jedynie „kaprys” (whims of murder). Wojna jest, jak widzieliśmy, zapoczątkowującym wstrząsem, ale „początek” ów nie daje nowego życia. Choć mowa o wnętrzu brzucha ziemi, jest to łono monstrualnych zmagań, których stawką jest śmierć. Także śmiercią tego, co nazywamy sensem. „[...] samotny człowiek z samotnym życiem został tutaj wystawiony na przemożny bezsens, na bezsens, którego nie mogli pojąć nazywając go co najwyżej za-

14 K. Kollwitz Letter and Diary Entries, w: German Expressionism. Documents from the End of the Wilhelmine Empire to the Rise of National Socialism, ed. R.C Washton, Long University of California Press, Berkeley 1994, s. 166-167. 
sraną wojną" ${ }^{\prime 16}$. Nie sens, lecz bez-sens, nie twórczy początek znaczenia, lecz ekskrement jako jedyne możliwe znaczenie.

\section{8.}

Gdy myśl życia jest widoczna na błękitnym, rozświetlonym niebie, myśl wojny pragnie za wszelką cenę stać się niewidoczna. Stąd trudności, na jakie napotykają ci, którzy chcieliby się jej przeciwstawić. Opór stawiany skrytemu i nieuchwytnemu przeciwnikowi jest szczególnie trudny. Najpierw trzeba by go zobaczyć, aby można było go określić, nazwać, przedstawić. Tymczasem myślenie wojenne zaciera ślady, pozwala zobaczyć ofiary, pieczołowicie skrywając to, co sprawia, że jeszcze przed ofiarniczą śmiercią człowiek zostaje zesłany do szczególnej sfery, w której milkną wszelkie słowa, zacierają się obrazy, głuchną dźwięki. Kollwitz nie zdołała uchwycić istoty wojny jako cienia kładącego się na myśleniu człowieka, jeszcze zanim cień ów zmiażdży jego ciało. Ostatniego grudnia 1917 roku Wilfred Owen zwierza się matce z podobnego wrażenia: wojna, z jednej strony tak okrutnie materialna, okazuje się całkowicie nieuchwytna, gdy staramy się rozpoznać spustoszenie, jakie czyni w ludzkiej twarzy i spojrzeniu. To szczególnie dotkliwe rozczarowanie dla świata, który wyrósł z XIX-wiecznego marzenia fizjognomiki o dokładnej i nie wzbudzającej wątpliwości lekturze znaczenia twarzy i jej mimiki. Poeta zostawi nam najpierw opis wojskowego obozu, będącego niczym „wybieg, na którym trzyma się bydło na kilka dni przed tym, nim pośle się je do rzeźni", a w tej iście Dantejskiej przestrzeni przykuje jego uwagę wyraz wszystkich twarzy (look on all faces): „Nie była to rozpacz ani przerażenie; było to coś bardziej przerażającego niż przestrach. To spojrzenie całkowicie niewidzące (blindfold look), pozbawione wyrazu, podobne do spojrzenia oczu martwego królika. Nigdy nikt tego nie namaluje, żaden aktor tego nie odegra. Żeby je opisać, musiałbym tam wrócić i być wśród nich"17. Doświadczenie wojny wydaje się wykraczać poza możliwość reprezentacji; zamknięte w sobie milczy, jakby ci, którzy stanowili jego podmiot, należeli do innego świata, którego realiów i języka nowy świat już nie zna. Milczenie nowoczesnej sztuki Malewicza, Rothki, Newmana, Becketta tutaj ma swoje źródła.

16 H. Broch Lunatycy, przeł. S. Błaut, Wydawnictwo Dolnośląskie, Wrocław 1997, s. 421.

17 W. Owen Collected Letters, w: The Penguin Book of the First World War Prose, eds. J. Glover, J. Silkin, Penguin Books 1989, s. 401. 
9.

Niepochwytność wojennego myślenia dewastującego twarz i oczy. Jej żywiołem jest światło jako „poświata”; zaciera ono kontury i zarysy przedmiotów, ale także czyni to samo z odrębnością ludzkiego podmiotu. Teraz nierozróżnialnego od innych i wraz z nimi niknącego w dymach. Co mogłoby stanowić przeciwieństwo owej śmiertelnej, lucyferycznej poświaty? Wobec niedostępności wysokiego nieba pozostaje tylko światło lampy towarzyszące lekturze. Ranny Jünger, odwieziony do punktu sanitarnego na tyłach, z podziwem patrzy na opiekującego się nim sanitariusza obdarzonego szczególnym zmysłem troskliwości. Ale najważniejsze jest co innego: cicha dramaturgia ludzkiego światła daleka od "spektaklu” bitewnej piekielnej elektryczności. „Ulgą napawał mnie już sam fakt, że mogłem go oglądać czytającego książkę przy świetle lampy"18. Żołnierz jako myśliciel wojny również skupia uwagę, ale skupienie to ogniskuje się na tym, co może okazać się zbawienne w danej sytuacji: miejscu wybuchu nieprzyjacielskiego pocisku, ruchu wojsk na przedpolu, przesuwaniu się linii ognia itp. Natomiast koncentracja czytającego jest zupełnie innej natury. Jest, by tak rzecz ująć, bezinteresowna. Znamienne, że postawę czytającego przy ogniu Bachelard przeciwstawi postawie myśliwego lub wojskowego. Czytającego charakteryzuje „bardzo szczególne skupienie uwagi, które nie ma nic wspólnego z koncentracją uwagi na czatach czy podczas obserwacji”' . Obserwator śledzący ruchy z okopu wie, że „wszystkie drogi uchodzą w czarną zgniliznę"20 ; czytający porusza się bezdrożami, bez mapy i drogowskazów. Nie panuje nad nim żaden przełożony, żaden sztab nie wykreśla jego ruchów i nie zaznacza jego pozycji. W czytaniu chodzi o „znalezienie własnego rytmu” i „własnego tempa"21, a trudno o coś bardziej przeciwnego wojskowemu drylowi wojny. Miał rację Kant w eseju o tym, czym jest oświecenie: tak długo, jak czytamy, tak długo demokracja wciąż jest możliwa. Wojna z jej światłem nieprzyświecającym lekturze zabija demokrację.

18 E. Jünger Wstalowych burzach..., s. 31.

G. Bachelard Wyobraźnia poetycka, przeł. H. Chudak, A. Tatarkiewicz, PIW, Warszawa 1975, s. 33.

G. Trakl Grodek, w: tegoż Poezje wszystkie, przeł. A. Lam, Instytut Mikołowski, Mikołów 2012, S. 199. 
10.

Myślenie, które czyni wojnę jako przejaw życia utajonego w przeciwieństwie do życia otwartego i nieznającego ograniczeń (makes war zamiast love), zsyła nas na powrót do jaskini Platona będącej świątynią przemocy i złudzenia. Platońska grota opisana w słynnym fragmencie VII księgi Państwa jest okopem, podziemnym schronem, ziemianką, w której zniewoleni ludzie karmieni są pozorami poznania. W jaskini „siedzą od dziecięcych lat w kajdanach; przykute mają nogi i szyje tak, że trwają na miejscu i patrzą tylko przed siebie; okowy nie pozwalają im obracać głów"22. Blask umieszczonego za nimi ogniska wyświetla na kamiennej ścianie cienie rzucane przez rzeczywiste przedmioty znajdujące się na zewnątrz.

\section{1.}

Z tego powodu wojna jest de-formacją światła. Reżyseria oświetlenia stanowi ważny element bitewnego spektaklu. Jej zadaniem jest skonstruować rzeczywistość na granicy widzialności, sprawić, że wielka eksplozja światła, rozpalenie ogromnego ogniska ukaże ledwie kontury przemykające wśród płomieni. Ernst Jünger notuje: „Stojąc na osłonach oglądaliśmy w zdumieniu wysoką jak wieża ścianę ognia nad angielskimi okopami, coraz to bardziej osnutą welonami kipieli krwawoczerwonych chmur. Spektakl zakłóciło łzawienie oczu i dotkliwe pieczenie błon śluzowych. Pędzone ku nam przeciwnym wiatrem opary własnych gazowych granatów otuliły nas wonią gorzkich migdałów"23. Ściana ognia i wrzenie krwawych chmur - tę wariację na temat czerwieni w duchu Edgara Allana Poe można także uznać za komentarz do wspomnianej już filozofii Heraklita, w której polemos czerpie siłę z metaforyki ognia: kosmos płonie, wszystko powraca do ognia i tylko ogień pozostaje żywy. Ale myślenie wojny odczytuje na nowo mit o Prometeuszu: człowiek skradł „ogień”, jakim są osiągnięcia matematycznej inżynierii, skradł go sam sobie, sprzeniewierzył go obracając do celów zniszczenia. Bachelard nazywa to kompleksem Prometeusza: „chcemy wiedzieć tyle, co nasi ojcowie, więcej niż nasi ojcowie, tyle co nasi władcy, więcej niż nasi władcy"24. Myślenie wojenne to myśl rozpędzona, która uznaje granice tylko o tyle, o ile pragnie

Platon Państwo, przeł. W. Witwicki, Wydawnictwo Alfa, Warszawa 1991, t. 2, s. 57.

E. Jünger Wstalowych burzach..., s. 208.

G. Bachelard Wyobraźnia poetycka..., s. 32. 
je przekroczyć i wyeliminować. Modelem takiego myślenia jest działanie barona Frankensteina dążącego do wydarcia naturze i Bogu tajemnic życia i w rezultacie życie to niszczącego. Człowiek wrzucony w wojnę jest „wtrącony w grozę rozpętanego rozumu, skierowany na jego służbę, ale go nie pojmujący, więzień nadrzędnego działania, więzień swojej irracjonalności [...]"25.

12.

Światło wy-myślone przez wojnę jest paradoksalnej natury: ukazuje i zakrywa jednocześnie. Ma za zadanie oświetlić tak, by uczestnik „spektaklu” został oślepiony, a więc by stracił ostrość widzenia. Postąpmy krok dalej: światło wojennego myślenia jest okrutną parodią empatycznego związania ze światem, jaki często znajduje wyraz w płaczu. Andrew Marvell medytował nad osobliwą antropo-teologiczną konstrukcją człowieka, którego oczy są instrumentem poznania i płaczu i to właśnie stanowi wyróżnik człowieczeństwa: "Tylko ludzkie oczy płaczą" (But only human eyes can weep) tłumaczy Stanisław Barańczak. Jacques Derrida idzie dalej w swym komentarzu, mówiąc o objawieniowej czy też apokaliptycznej mocy owej szczególnej ślepoty władnącej płaczącymi oczami ${ }^{26}$. W doświadczeniu bitewnym opisanym przez Jüngera oczy łzawią nie dlatego, że zafascynowało je to, co ukazało się po rozdarciu zasłony - rejon przyszłego, ostatecznego ocalenia przygotowanego przez Boga kładącemu kres łzom („Nie będą już łaknąć ani nie będą już pragnąć, i nie porazi ich słońce ani żaden upał, bo paść ich będzie Baranek, który jest pośrodku tronu, i poprowadzi ich do źródeł wód życia: i każdą łzę otrze Bóg z ich oczu", Ap.7.16-17). Oczy wojny płaczą, bowiem zostały zaatakowane przez gaz - osiągnięcie ludzkiej techniki. Nie chodzi w tych łzach o wzniosłą intensyfikację życia u-wiecznionego, lecz jedynie o śmierć. „Z niepokojem obserwowałem, jak kilku żołnierzy zaczynało kaszleć i dusić się, aż w końcu zerwało maski z twarzy", kończy swój opis Jünger.

13.

De-formacja światła jest także de-formacją apokaliptyczności. Ogień był zawsze boskim atrybutem („To mówi Syn Boży: Ten, który ma oczy jak płomień

25 H. Broch Lunatycy..., s. 851.

26 J. Derrida Memoirs of the Blind. The Self-Portrait and Other Ruins, przekł. ang. P.A. Brault, M. Naas, University of Chicago Press, Chicago 1993, s. 127. 
ognia" Ap.2.18); potrafił oślepić, ale ostatecznie był wedle św. Augustyna „światłością jedyną". Gniew ognia tej światłości miał moc potępiania; zbawionym natomiast otwierał oczy. Ślepota stanowiła formę odzyskania innego, duchowego spojrzenia; jak dobitnie dowodzi przykład św. Pawła, utrata wzroku była dramatycznym apogeum procesu metanoi. W konsekwencji to, co widzieliśmy poprzednio, teraz, po owym radykalnym uderzeniu, okazuje się złudzeniem ślepca. Boskie światło jest także siłą zespalającą: to, co w świetle dostępnym zmysłom jest jedynie „uwodzicielsko błogie i bardzo niebezpieczne", sprzyja izolowaniu się indywiduum, które powierza się owym skutecznie złudnym przyjemnościom. Inaczej ze światłością Boga: „To jest światłość, jedyna, i nie ma oprócz niej światłości innej. I jedność stanowią wszyscy, którzy widzą ją i miłują"27. Piekielne światło wojny tworzy upiorną namiastkę wspólnoty, w której pozbawione twarzy indywidua skupiają się w jednej anonimowej masie. Wojenne myślenie de-formuje pojęcie wspólnoty, fałszując dotychczasowe znaczniki: „uwodzicielskie” jest tutaj to, co św. Augustyn przypisywał wyodrębnionemu światu jednostki - zbiorowość masowej organizacji wojska i społeczeństwa traktowanych jako robotnicy wojny poddani totalnej mobilizacji.

\section{4 .}

Światło myślenia wojennego jest „poświatą”, chorobliwym, piekielnym blaskiem „rac”,,,rakiet”, wybuchających pocisków. Herbert Read mówi o „mdłym i mglistym świetle”, a dull and hazy light, właściwym „Rozpadowi, co zawisł nad wszystkim"28. Jest światłem po-świetle. Imitacją światła, którą aparat propagandy przedstawia jako światło jedynie prawdziwe, zaprzęgając do tego zadania takie pojęcia jak „honor” czy „sprawiedliwość”. To kolejna de-formacja, jakiej dopuszcza się wojenne myślenie: chce ono dowieść godności tych fundamentalnych pojęć w sytuacji, w której jednostka nie ma w istocie wyboru. Decyzja zostaje jej odjęta mocą trudnego do przezwyciężenia ciężaru stechnicyzowanego życia i równie stechnicyzowanej techno-biurokracji wojny. Jünger zapisuje zaskakujące zdanie, które powinno stanowić dzisiaj ostrzegawczy wstrząs. Myśląc o honorze i obowiązku tkwiącego w okopach żołnierza, nadaje tym pojęciom charakter zgoła potworny: oto przestają one odnosić się w jakiejkolwiek mierze do ludzkiego indywiduum, lokując się 
w anonimowości „narodu”: „Każdy stał się szalony i nieobliczalny, rzucony w ten nieludzki krajobraz, gdzie śmierć straciła znaczenie, a chęć życia przeniosła się na naród; wszyscy stali się ślepi i niewrażliwi na dolę osobistą"29. Dlatego podstawowym warunkiem, by "to wszystko znów się nie powtórzyło", jest odzyskanie osobowego wymiaru takich pojęć, jak honor i obowiązek; ich przewartościowanie wyzwalające spod presji wielkich ideologemów, takich jak „naród”. Dlatego Johannes Becher radzi żołnierzowi: „Gniewnie roztrzaskasz na tysiąc kawałków / przestępczy karabin. / Nie pomny na nic uchylisz się od swego 'przeklętego / obowiązku i powinności' / I z otwartą ironią odmówisz wszelkim wyzyskiwaczom, / tyranom i chlebodawcom / pełnienia swej taniej łajdackiej służby"30. Wojenne myślenie jest nadzwyczaj podatne na działanie wszelkich ideologemów; można rzec, że jest myśleniem, które wcześniej czy później zostaje owymi ideologemami zatrute i zaciemnione.

\section{5.}

Z perspektywy czasu i doświadczenia powtarzalności tego, co nie miało się "znów powtórzyć", można postawić dwie tezy, obie dotyczące owych ideologemów. Pierwsza głosiłaby, że wiek XX rozpoczyna się od idei wojny jako instrumentu ideologemu państwa narodowego i dalszy przebieg dziejów wzmacniał jego oddziaływanie, aż po wzbudzenie krytycznej jego oceny po II wojnie światowej. Druga teza wyprowadzałaby się z pierwszej: nieoczekiwane odnowienie i wzmocnienie idei narodowej na początku XXI wieku nie zapowiada niczego dobrego, odnawia dychotomię przyjaciela i wroga, swojskiego i obcego, i tym sposobem jest gotowaniem się do wojny. Zatem, aby „to znów nie miało się powtórzyć", należy przeprowadzić poważną krytykę pojęcia państwa narodowego, nie po to, aby zakwestionować jego historyczne znaczenie, lecz by zwrócić uwagę na niebezpieczeństwa, jakie niechybnie niesie ono z sobą.

\section{6.}

Sięgnijmy znów do książki Wincentego Lutosławskiego. Wizja przyszłości Europy w niej zarysowana opiera się na poszukiwaniu sposobów ukształtowania się państwa narodowego w opozycji do dominującego u schyłku XIX wieku państwa zaborczego. Trwałość i nieuchronność wojny jako constans

\footnotetext{
29 E. Jünger W stalowych burzach..., s. 272.

30 J. Becher Człowieku, powstań!, s. 181.
} 
dziejów wynika z heterogenicznego charakteru najpotężniejszych państw. „Nowożytne państwo, jednoczące zwykle wiele ludów pod jednym rządem, na wojnie stoi, z wojny powstało, przez wojnę zginie" $(L O, 21)$. Dzieje to, wedle Lutosławskiego, historia zmagań ludów o wyzwolenie, zaś kryzys przełomu wieku polegał na wyjątkowym spleceniu się dynamiki dążeń niepodległościowych oraz technicznych możliwości prowadzenia działań przeciwko hegemonom. Nowoczesność to proces podboju i uzależniania ludów drogą ekonomiczną, militarną i dyplomatyczną, proces, który od początku XX wieku dochodzi do kresu. „Minął czas kompromisów i wybiegów dyplomatycznych”, nastał czas „strasznej wojny”. Już po jej zakończeniu Lutosławski pisał, że walka nie była „konfliktem ambitnych jednostek, lecz dwóch przeciwległych form życia: z jednej strony samorząd narodów; z drugiej zaborczość państw i dynastii" ${ }^{31}$. Trudno nie podziwiać precyzji przepowiedni filozofa opublikowanej w 1910 roku: „Wojna ta wieloletnia przewyższy grozą wszystkie dawniejsze. Nie potrzeba wysilać zbytnio wyobraźni, by opisać te bitwy, w których miliony żołnierzy, tysiące statków powietrznych będą po obu stronach. Niespodziewane i nieprzewidziane sposoby zniszczenia się objawią, całe miasta poznikają prawie bez śladu z powierzchni ziemi, choroby zaraźliwe będą podstępnie szczepione wrogom - będzie to wielka walka o śmierć i życie między narodami a wybujałą nadmiernie państwowością" (LO, 36). Ciekawe, że dla Lutosławskiego zbrojny kataklizm 1914-1918 jest tylko spektakularnym rozbłyskiem dłuższego stanu "zbrojnego pokoju”, którego gorączkowy kryzys przypadł na rok 1911: „Szczególnie uwypukla się tu ciągłość wypadków od 1 lipca 1911 roku, od chwili, gdy [niemiecki - T.S.] okręt 'Panther' wpłynął do Agadiru. Wojna trwa nie cztery lata, lecz siedem, choć pierwsze trzy lata tej wojny nie miały wielkiego wpływu na wewnętrzne życie zachodnich narodów"32.

\section{7.}

Era pokoju rozpoczyna się więc w momencie „unarodowienia państwa”, co dla Lutosławskiego jest równoznaczne z przejściem od brutalnej polityki silnych jednostek dbających o własne interesy do panowania polityki wspólnotowego ducha. Zmianę tę przedstawia filozof jako dziejowy ruch od celów „cielesnych" do „duchowych”: „Przejście zatem od polityki państwowej do 
polityki narodowej jest przejściem od prawa pięści do panowania ducha w ludzkości” $(L O, 65)$. „Prawo pięści” to nic innego, jak panujący powszechnie stan wojny narzucający swoje wymogi także pokojowi i de-formujący życie społeczne. Pół wieku przez Patočką Lutosławski dostrzega sytuację XX wieku jako stan wojennego napięcia, który sprawia, że system polityczny jest niczym innym, jak formą wojennej mobilizacji. „Absurdalna”, jak pisze Lutosławski, wysokość budżetów wojskowych de-formuje pojęcie pokoju, który staje się „nie-pokojem”, pokojem zawłaszczonym przez wojnę. „Na utrzymanie zbrojnego pokoju wydaje się więcej ludzi, czasu, pieniędzy niż na dawniejsze najkrwawsze wojny” ( $L O, 21)$. Ów „nie-pokój” jest szczególnej natury. Sięgnąwszy do niemieckich tekstów odnajdziemy pojęcie Unfriede oznaczające "niezgodę" i etymologicznie związane z „pokojem” (Friede). Zatem to, co Lutosławski trafnie określa w duchu późniejszej refleksji Patočki stanem „zbrojnego pokoju”, jest nie-zgodą na zgodę na zastany stan rzeczy, ale nie po to, by stan ów odmienić, lecz przeciwnie - by go rozbudować, wzmocnić i rozszerzyć zasięg jego panowania. „Narody zaborcze [...] z natury rzeczy szukają coraz to nowych zdobyczy, nowych poddanych, nowych prowincji, gdzieby się znalazły miejsca dla nadprodukcji wyższych urzędników cywilnych i wojskowych" $(L O, 27)$.

\section{8.}

Kres państwom zaborczym, których modus vivendi określa „zbrojny pokój” (Lutosławski), „nie-pokój” (Becher) lub „stan wojny” (Patočka), położą więc związki narodów żyjących na własnych terytoriach. W romantycznej retoryce Słowackiego Lutosławski tak opisuje zmierzch dotychczasowego biegu dziejów: „Ogień niebieski miłości narodu i świadomości narodowej stopi pancerze militaryzmu dziś zaskorupiającego współczesne państwa i pochłaniającego żywotne siły ich obywateli" $(L O, 71)$. Wieczny pokój, któremu Lutosławski poświęca osobny rozdział, opierać się będzie na działaniu międzynarodowych praw oraz na „unii” zapewniającej państwom „trwały rozwój społeczny i wcielenie w życie ideałów ducha każdego narodu dla pożytku całej ludzkości" $(L O, 72)$. Odkładając na inną okazję analizę prawnego projektu unii państw europejskich stworzoną przez autora Ludzkości odrodzonej wskażmy krytycznie, wykorzystując doświadczenia dalszego biegu dziejów, dwa elementy, które niczym siły tektoniczne wstrząsają konstrukcją Lutosławskiego. Po pierwsze, wieczny pokój nie jest wolny od napięć i konfliktów. Sam autor wydaje się świadomy tego problemu, którego geo-politycznym symbolem 
jest granica. „Od tych granic bowiem zależy spokój świata”, stwierdza dobitnie filozof i chociaż mówi o "unii" i międzynarodowym trybunale mającym rozstrzygać spory, cień powątpiewania jest w jego refleksji widoczny („Bardzo trudnem będzie rozgraniczenia państw narodowych powstających na gruzach dzisiejszej Austrii...", LO, 52).

19.

I drugi element - naród, którego problematyczność jest absolutnie źródłowa dla zrozumienia dziejów. Wiemy, że krytycznym zwrotem w dziejach jest, w opinii Lutosławskiego, przesilenie prowadzące do „unarodowienia państwa” i zwycięstwa ducha nad „cielesnością" imperialnej zaborczości. Niewątpliwie I wojna światowa, która - przewiduje Lutosławski - „nie będzie jak dotychczasowe wojny europejskie zlokalizowanym pożarem” ( $L O$, 32), stworzyła nową mapę Europy z nowymi granicami nowych państw, ale dzisiaj trzeba do niezachwianej wiary w „naród” i jego rzekomy „wieczny pokój” odnieść się z krytyczną rezerwą. Sam Lutosławski, choć nie zmniejsza to jego zaufania do tego pojęcia, dostrzega, że "naród” jest kategorią ekskluzywistyczną. „Państwami rządziłyby narody - więc kto do żadnego narodu nie należy, ten nie miałby żadnego udziału w administracji w jakimkolwiek państwie, a każdy obywatel mógłby tylko być dopuszczonym do praw politycznych w państwie, w którym jego naród ma udział" $(L O, 57)$. Wydarzenia następujące po Wielkiej Wojnie postawiły przed pojęciem narodu wielki znak zapytania. W 1910 roku Lutosławski upatruje w nacjonalizmie nadziei w sporze z imperializmem; 22 lata później Bertrand Russell powie, nie bez racji, że "nacjonalizm jest niewątpliwie największym złem naszych czasów”, i nazwie go "niszczycielską chorobą" ${ }^{33}$ przeciwstawiającą się wychowaniu, które "mogłoby z łatwością rodzić poczucie solidarności z całą rasą ludzką i zrozumienie wielkiej wagi współpracy międzynarodowej”34.

\section{0.}

Nie mylił się autor Ludzkości odrodzonej, przypisując „narodowi” rolę przełomową w dziejach schyłku XIX wieku. Nie możemy jednak podzielić jego

33 B. Russell Wychowanie a ustrój społeczny, przeł. J. Hosiassonówna, Towarzystwo Wydawnicze Rój, Warszawa 1933, S. 159. 
wiary w to, że „unarodowienie państwa” ma być źródłem „wiecznego pokoju”. Hekatomba II wojny światowej ledwie 21 po tym, jak w listopadzie 1918 roku zamilkły działa, dowiodła próżności owych nadziei. Jedną z wielkich lekcji Wielkiej Wojny powinna być nieufność do „narodu” jako kategorii będącej instrumentem fałszywego zrównywania jednych w poczuciu wyższości nad drugimi. Nic dziwnego zatem, że Denis de Rougemont, jeden z ojców założycieli nowej Europy, warunkował przyszłość kontynentu od stopnia zdystansowania się wobec tradycji „narodu”. W 1950 roku pisał: „[...] współczesne Państwa-Narody przyniosły Europie tylko nieszczęścia: rozpoczynającą się od lat 1880-tych potężną falę kolonializmów, śmierć trzydziestu ośmiu milionów w czasie dwóch wojen, schyłek tysiącletniej pozycji, upokorzenie w obliczu nowych potęg światowych"35.

21.

Wojna 1914-1918 zrodziła fałszywe nadzieje, które zostały pogrzebane przez II wojnę światową, a dzisiejszy zwrot w stronę nacjonalizmów i fałszywych patriotyzmów dowodzi, że jej lekcja poszła w dużej mierze na marne. A lekcja ta brzmiała następująco: w stechnicyzowanym świecie mobilizacji mas sens życia będzie w coraz większym stopniu narzucany przez dysponentów ideologemów. Jedynym ratunkiem jest mądry indywidualizm polegający na (1) odzyskaniu przez jednostkę niezawisłości krytycznej refleksji umożliwiającej przejrzenie chytrej gry prowadzonej przez polityków i następnie (2) tworzenie się grup i organizacji pozapaństwowych rozszerzających oddziaływanie owej krytycznej refleksji i w konsekwencji prowadzących do zmian. Jeżeli rację ma Jan Patočka, twierdząc, że „ogólną ideą pierwszej wojny światowej było z wolna rodzące się przekonanie, że nie istnieje nic takiego, co byłoby obiektywnym sensem świata i rzeczy, i że realizacja takiego sensu w dostępnym człowiekowi zakresie jest sprawą siły oraz władzy", to zatem na każdym indywiduum spoczywa ciężar wydobycia owego znaczenia. By tak się stało, musi ono wyswobodzić się spod władzy politycznej i społecznej maszynerii. Dobrze opisuje tę sytuację Esch w powieści Brocha: „Czasami jest tak, jakby świat był tylko jedną straszną maszyną, która nigdy nie ustaje ... wojna i wszystko ... toczy się to według zasad, których człowiek nie pojmuje ... według zuchwałych, pewnych siebie zasad, inżynierskich zasad ... każdy

35 D. de Rougemont List otwarty do Europejczyków, przeł. A. Olędzka-Frybesowa, „Literatura na Świecie" $1991 \mathrm{nr}$ 10, S. 21. 
musi działać, jak mu to jest przepisane, każdy twarzą do przodu ... każdy jest maszyną, którą widać tylko z zewnątrz [...]"36. Poetycki wyraz znalazł dla tej prawdy Wilfred Owen, pytając: „Jakież podzwonne pożegna tych, co jak bydło dziś giną? / Chyba li dział rozsierdzonych potworna im zagra muzyka"37.

22.

To, że zaciemnione myślenie wojny narzuca zaciemnienie i spycha człowieka do podziemnych schronów, znajduje teoretyczne uzasadnienie w odwróceniu biegu metafory: myślenie wojny nie wyprowadza człowieka z jaskini, jak projektowali to Bacon i Kartezjusz; przeciwnie - zatrzymuje nas w niej, przy czym nie przedstawia owego podziemia jako domeny ciemności, lecz właśnie jako dziedzinę świetlistości prawdy i to prawdy powszechnej. Ciemna poświata wojny skonstruowana przez siły dnia, racjonalności rozwiniętej techniki („Wojna jest promotorem techniki i nauki, niszczycielką świata artystycznego"38), z powodzeniem stara się wpoić wszystkim hipnotyczne przekonanie, że jest niczym innym jak światłem. Pokój, jakiemu miały służyć osiągnięcia nauki, staje się formą wojny i w tej nowej postaci szuka podziwu dla swej skuteczności zaprzęgniętej do służby nie ludzkiej wspólnoty, lecz wydzielonej grupy (np. narodu). Jan Patočka słusznie upatruje w I wojnie światowej wydarzenia bez precedensu w dziejach.„Właśnie ona ukazała, że przemiana świata w laboratorium uruchamiające zasoby energii akumulowanej przez miliardy lat musi się dokonywać w formie wojny” ${ }^{39}$. I dalej: „Siłami, które przez cztery lata posyłają miliony ludzi w gehennę ognia, są siły dnia, front zaś jest miejscem przez cztery lata hipnotyzującym aktywność całej epoki industrialnej [...]"40. Siły dnia, zaprojektowane w nowoczesnym świecie przez oświecenie, stworzyły rodzaj sztucznego dnia, który jest efektem myślenia wojennego jako, jak wynika z uwagi Patočki, nieuniknionego skutku ubocznego procesu modernizacyjnego. Industrialność będąca zakrzepłą formą myślenia matematyczno-przyrodniczego znalazła zrozumiałe przedłużenie w okopanej myśli

36 H. Broch Lunatycy..., s. 658.

37 W. Owen Hymn dla skazanej na śmierć młodzieży, przeł. J. Wittlin, w: Czas niepokoju..., s. 239.

E. Jünger Robotnik, przeł. W. Kunicki, PWN, Warszawa 2010, s. 300.

39

J. Patočka Wojny XX wieku i wiek XX jako wojna, przeł. J. Zychowicz, w: tegoż Eseje heretyckie..., S. 170. 
wojennej restytuującej metaforykę, ale i praktykę życia w Platońskiej jaskini. Nie dziwi nas więc inwokacja Johanessa Bechera splatająca wszystkie te nici: „Dalej z okopów fabryk przytułków kloak, całej tej / piekielnej spelunki! / Chóry słońc hymnicznie wywołują ślepców z jaskiń"41.

23.

Kajdany mieszkańców Platońskiej groty stają się więzami bezdusznego wojskowego regulaminu, okowy niepozwalające na spojrzenie w inną stronę, to propagandowo-retoryczna machina spod znaku dulce et decorum est pro patria mori. Podkreślamy powszechność wojennego projektu, bowiem późna nowoczesność dokonała znaczącej modyfikacji metafory jaskini. Dla Bacona idola specus, czyli idole jaskini, oznaczają monadyczne zamknięcie indywiduum w kręgu jego subiektywnych wyobrażeń, tymczasem ich późnonowowczesna wersja, wypracowana przez myślenie wojenne i znakomicie praktykom wojny służąca, zabiega o jeden powszechnie obowiązujący model świata i naszych wobec niego zobowiązań. Jak komentuje Hans Blumenberg: „Wyjście z jaskini nie jest już wyjściem pojedynczego mędrca na pełne światło drogą paidei, lecz metodą rozumianą jako technika zdobywania dla wszystkich większego wspólnego świata"42.

\section{4.}

Sama retoryka wiele nam tu wyjaśni. Nie mówi się wszakże o „wyjściu”, lecz o „zdobywaniu”; nie o „paidei”, lecz o „technice”. Nie chodzi bowiem o kształcenie czy to, co Schiller nazywał „zabawą" przyczyniającą się walnie do "pięknego obcowania"43. Przeciwnie - gdy w przypadku paidei arcyważny jest namysł, technika wymusza szybkie automatyzmy i to właśnie jest celem myślenia wojennego, które zainteresowane jest połączeniem siły i posłuszeństwa. Jüngerowski „robotnik” będący idealnym modelem takiego człowieka „walczy i umiera w urządzeniach, nie tylko bez «wzniosłych idei», ale świadomie je odrzucając Jego etos polega na precyzyjnej

41 J. Becher Człowieku powstań!, s. 180.

42 H. Blumenberg Światło jako metafora prawdy. Przedpole filozoficznego kształtowania pojęć, przeł. Z. Zwoliński, „Kronos" 2013 nr 2, s. 42.

43 F. Schiller Listy o estetycznym wychowaniu człowieka, w tegoż Pisma teoretyczne, przeł. J. Prokopiuk, Aletheia Warszawa 2011, s. 155. 
obsłudze aparatury. Nie może się zastanawiać, nie ma wglądu w całość" ${ }^{4}$. $\mathrm{Z}$ jednej strony mamy więc światło paidei należące do (wracam znów do znakomitego tekstu Schillera) „radosnego państwa gry i pozoru”, w którym "popęd formy zdejmuje z człowieka więzy stosunków i uwalnia go od wszystkiego, co jest dlań przymusem fizycznym lub moralnym"45 z drugiej - brutalne podbijanie świata i podporządkowywanie go interesom wydzielonych grup. Sam Blumenberg posługuje się militarną retoryką, używając w podtytule swego eseju słowa "przedpole” (Vorfeld), sugerując, że filozofia jest niczym innym, jak logomachią. Patočka, mówiąc o "gehennie ognia", daje do zrozumienia, że ześlizgnięcie się świata w wojnę jest powrotem do bałwochwalstwa i zdesakralizowanej śmierci w królestwie Molocha. Wojenne myślenie, rdzenny wytwór kultury Zachodu, de-formuje także przebieg jego dziejów, wprowadza pokrętne meandry i zwroty, w których nurt wydarzeń, niczym powódź, zrywa i niszczy mosty, które chcielibyśmy uznać za znamię postępu.

\section{5.}

Przytoczmy znamienne dwa wersy z wojennego wiersza Herberta Reada: dusza zwraca się do zbrutalizowanego przez wojnę ciała mówiąc: „Unoszę się nad twymi bezsławnymi cechami / które elektryczne światło odcięło od Nieba"46. Ciało poddane presji wojny traci swe cechy charakterystyczne nie tylko dlatego, że zostało zmasakrowane, wdeptane w błoto (Wilfred Owen napisze, że wojna to brnięcie „śród błota i mięsa" ${ }^{47}$ ), w najlepszym razie pochowane we wspólnej mogile, ale jeszcze zanim to się stanie, wojna wymaże charakterystyczne cechy ciała, bowiem te potwierdzają niepożądaną odrębność istnienia jednostki. Wojna eliminuje takie poczucie, czyniąc z ciała powszechnik; nie ma ono już indywidualnych cech charakterystycznych, ma jedynie cechy wspólne. Ciało stworzone przez wojnę i na jej potrzeby jest jak Lewiatan ze słynnej ryciny frontyspisu dzieła Thomasa Hobbesa: gigantycznym ciałem złożonym z milionów ciał, które pozbawiono cech indywidualnych.

\footnotetext{
44 E. Jünger Robotnik..., s. 301.

45 F. Schiller Listy..., S. 154.

46 H. Read The End of a War, w: First World War Poetry, ed. J. Silkin, Penguin Books 1981, s. 150-165.

47 W. Owen Obłąkani, przeł. J. Wittlin, w: Czas niepokoju..., s. 327.
} 
26.

W tym znaczeniu Humpty Dumpty jest mistrzem wojny. Po pierwsze dlatego, że doskonale zdaje sobie sprawę z tego, że pierwszym polem bitewnym jest język, którym wygrywa się ludzkie umysły, narzucając im obraz świata służący interesom władzy.„Gdy ja używam jakiegoś słowa [...] oznacza ono dokładnie to, co mu każę oznaczać..., ni mniej, ni więcej"48. W konsekwencji pozostaje tylko jedno pytanie „kto ma być panem ... to wszystko”. Po drugie, zapanowawszy nad językiem, tzn. ujednoliciwszy obowiązującą powszechnie wizję świata, Humpty Dumpty może z powodzeniem pozbawić ciało wszelkich cech indywidualnych. A ponieważ twarz jest miejscem szczególnym, wszak - jak zauważa Alicja na długo przed Levinasem - „ludzi rozpoznaje się zwykle po rysach twarzy", należy twarz ujednolicić, stworzyć twarz powszechną, twarz właśnie nie do rozpoznania, ponieważ w myśleniu wojennym żadne rozpoznanie, oprócz rozpoznania pozycji wroga, nie jest potrzebne. „Masz taką samą twarz jak wszyscy pozostali ... dwoje oczu [...] nos pośrodku, a pod nim usta. Zawsze się to powtarza"49. Gdy użycie bojowego gazu pod Ypres wymusiło posługiwanie się maską gazową (obserwując męczarnie porażonych chlorem, Jünger postanawia „nigdy nie wychodzić bez maski gazowej, bowiem do tej pory z niewiarygodną lekkomyślnością pozostawiałem ją w schronie"50), powołało do życia idealną twarz wojennej fenomenologii: twarz taką samą dla wszystkich, a więc nie do rozpoznania. Więcej, twarz ponad potrzebą i koniecznością rozpoznania.

L. Carroll O tym, co Alicja odkryła po drugiej stronie lustra, przeł. M. Słomczyński, Czytelnik, Warszawa 1972, s. 89 . 


\section{Abstract}

\section{Tadeusz Sławek}

THE INSTITUTE OF LITERARY RESEARCH OF THE POLISH ACADEMY OF SCIENCES (WARSAW)

The Dark Light of War

In his reading of World War I writing and poetry Sławek shows that war, which represents an obscured form of thought, pushes man into underground shelters and reverses the classical metaphor. As an obscured form of thought, war does not lead humankind out of the cave, as argued by Bacon, Descartes and many of the Enlightenment philosophers who were influenced by them. Quite to the contrary, war keeps humankind captive, and it makes every effort to present their captivity not as a space of darkness but as the luminous space of truth - a truth that is universally binding. The obscured thinking of war mobilizes everyone around a single truth that cannot stand opposition. What was unprecedented about World War I is the fact that the state of peace, which the achievements of science had been supposed to serve, became a form of war and in this new form sought admiration for its effectiveness.

\section{Keywords}

war, gaze, light, thought, nation 